\title{
UJI EFEKTIVITAS BUBUK BAWANG PUTIH (Allium sativum) TERHADAP PERTUMBUHAN BAKTERI Edwardsiella tarda
}

\section{THE TEST EFFECTIVENESS OF GARLIC (ALLLUM SATIUM) AGAINST THE GROWTH OF Edwardsiella Tarda BACTERIAL}

\author{
Farah Diana $^{1^{*}, \text { Ainal Marziah }}{ }^{2}$ \\ ${ }^{1}$ Jurusan Akuakultur, Fakultas Perikanan dan Ilmu Kelautan Universitas Teuku Umar, Aceh Barat \\ ${ }^{2}$ Jurusan Perikanan, Fakultas Perikanan dan Ilmu Kelautan Universitas Teuku Umar, Aceh Barat \\ *Korespondensi: farahdiana@utu.ac.id
}

\begin{abstract}
ABSTRAK
Penelitian ini bertujuan untuk mengetahui tingkat Efektivitas bubuk bawang putih terhadap Pertumbuhan bakteri Edwardsiella tarda. Penelitian ini dilaksanakan pada bulan Juli tahun 2017 di Laboratorium Kesehatan Ikan Balai Budidaya Air Payau (BBAP) Ujung Batee Kabupaten Aceh Besar Provinsi Aceh. Penelitian ini bersifat eksperimen dengan menggunakan Rancangan Acak Lengkap (RAL) pada 5 konsentrasi dan 3 ulangan. Perlakuan yang digunakan adalah konsentrasi penambahan ekstrak bubuk bawang putih pada beberapa dosis yaitu P0 (tanpa perlakuan), P1 (5 $\%)$, P2 (6\%), P3 (7 \%), P4 (8\%). Hasil dari uji penelitian ini didapatkan tingkat efektivitas bubuk bawang putih (Allium sativum) terhadap pertumbuhan bakteri Edwardsiella tarda menunjukkan bahwa bawang putih memiliki efek menghambat pertumbuhan bakteri. Hasil dari analisis data didapatkan bahwa pengaruh daya hambat terdapat pada pemberian bubuk bawang putih $8 \%$ berpengaruh terhadap pertumbuhan Edwardsiella tarda. Berdasarkan klasifikasi respon terhadap pertumbuhan bakteri, bubuk bawang putih tergolong memiliki efektifitas kuat dalam menghambat pertumbuhan bakeri Edwardsiella tarda jika konsentrasi dilakukan dengan persentase yang tinggi akan sangat bagus untuk menghambat pertumbuhan bakteri Edwardsiella tarda.
\end{abstract}

Kata kunci: Bubuk bawang putih, efektivitas, pertumbuhan bakteri, Edwardsiella tarda.

\begin{abstract}
This research was conducted in order to determine the effectivity of garlic extract (Allium sativum) as antifungal on tawes eggs (Puntius javanicus) and to know the effect of garlic extract (Allium sativum) as antifungal on tawes eggs (Puntius javanicus). This research was conducted in July 2015. This reasearch used experimental designs and Completely Randomized Design method with four treatments and three replications. The treatment was applied by adding garlic extract with P0: without treatment, P1: $5 \%, \mathrm{P} 2: 6 \%, \mathrm{P} 3: 7 \%$, and P3: $8 \%$. The rusuit of the effectiveness tes against the growth of these bacterial is inhibiting bacterial growth Edwardsiella Tarda, based on the classification of response to bacterial growt garlic classifled as having strong effectiveness in inhibiting the growth of bakery Edwardsiella Tarda, if concentration do with a high percentage would be great for inhibiting bacterial growth Edwardsiella Tarda.
\end{abstract}

Keywords: Garlic powder, effectiveness, bacterial growth, Edwardsiella Tarda

*Fakultas Perikanan dan Ilmu Kelautan, Universitas Teuku Umar Korespondensi : Jurusan Akuakultur, Fakultas Perikanan dan Ilmu Kelautan, Universitas Teuku Umar, Kampus UTU Meulaboh, Alue Peunyareng 23615, Telp: +62 81360272409, email: farahdiana@utu.ac.id 


\section{PENDAHULUAN}

Bawang putih merupakan salah satu tanaman yang berkhasiat obat. Bawang putih berbentuk menyerupai gasing, baunya menyengat, berwarna putih, berasal dari familia Alliaceae dengan nama latin Allium sativum. Bawang putih mengandung minyak asiri, dialil sulfida, aliin, alisin, enzim alinase, saponin, ftavonoid, polifenol, vitamin A, B, dan C (Departemen Kesehatan RI, 1995). Salah satu zat aktif yang terkandung dalam bawang putih adalah anti mikroba, selain it u minyak atsiri adalah alisin. Alisin dapat membunuh mikroba secara efektif, seperti kuman penyebab infeksi flu, gastroenteritis atau demam. Alisin dipercaya dapat membunuh bakteri Gram positif dan Gram negatif (Iyam dan Tajudin 2003).

Menurut Millner (2001), Sifat anti mikroba bawang putih telah diujicoba pada beberapa jenis bakteri seperti Haliotis Asinina dan beberapa jenis bakteri lainnya, namun belum pernah di ujicoba pada bakteri jenis Edwardsiella tarda. Bawang putih dapat digunakan dalam tiga bentuk, yaitu tepung bawang putih (TBP), minyak bawang putih (MBP) dan ekstrak bawang putih (EBP). Salah satu penyakit pada ikan adalah bakteri Edwarsiella tarda. E. Tarda adalah bakteri penyebab Edwardsiellosis pada ikan, bersifat Gram negative, bergerak dengan flagella, tidak membentuk spora atau berkapsul, ukuran $(0,3-1,2) \mathrm{x}(1,0-6,03) \quad \mu \mathrm{m} . \quad$ E. Tarda dapat hidup di lingkungan air tawar dan air laut dengan kisaran suhu pertumbuhan 10$39^{\circ} \mathrm{C}$. Serangan E. Tarda bersifat sistemik dalam berbagai kelompok umur dan populasi ikan (Ewing dkk,. 1965).

Sejauh ini, penanganan penyakit yang disebabkan oleh E. Tarda masih menggunakan obat-obatan yang relatif mahal dan bahan alami yang sulit didapati. Salah satu tanaman yang mempunyai khasiat obat dan paling mudah ditemui adalah bawang putih (Allium sativum L.). Informasi paling awal tentang khasiat obat tanaman dimulai sekitar tahun 3000 SM oleh bangsa Cina (Banerjee dan Maulik, 2002). Berdasarkan uraian diatas, penulis ingin melakukan penelitian tentang uji efektivitas bubuk bawang putih (Allium sativum Linn) terhadap pertumbuhan bakteri Edwardsiella tarda.

Tujuan penelitian ini adalah untuk mengetahui tingkat efektifitas bubuk bawang putih (Allium sativum) berdasarkan konsentrasi yang berbeda terhadap pertumbuhan Bakteri dan untuk mengetahui seberapa besar pengaruh yang diberikan oleh bubuk bawang putih terhadap pertumbuhan Edwardsiella tarda. Hasil penelitian ini diharapkan dapat menjadi informasi ada Sebagai sumber informasi dan acuan peneliti terhadap tingkat efektifitas bubuk bawang putih (Allium sativum).

\section{METODE PENELITIAN}

Penelitian ini telah dilaksanakan pada bulan Juli tahun 2017 di Laboratorium Kesehatan Ikan Balai Budidaya Air Payau (BBAP) Ujung Batee Kabupaten Aceh Besar Provinsi Aceh.

\section{Alat dan Bahan}

Adapun alat-alat yang digunakan dalam penelitian ini ditunjukkan pada table berikut:

Tabel 1. Alat yang digunakan dalam penelitian

\begin{tabular}{|c|c|c|}
\hline No & Alat & Fungsi \\
\hline 1. & Petridish & Sebagai media/wadah \\
\hline 2. & Incubator & $\begin{array}{l}\text { Sebagai tempat } \\
\text { penyimpanan }\end{array}$ \\
\hline 3. & $\begin{array}{l}\text { Laminary } \\
\text { Air Flow }\end{array}$ & Sebagai tempat pengerjaan \\
\hline 4. & Jarum Ose & Untuk mengambil bakteri \\
\hline 5. & $\begin{array}{l}\text { Lampu } \\
\text { Bunsen }\end{array}$ & Untuk mambakar jarum ose \\
\hline 6. & Auto Clave & Untuk sterilisasi \\
\hline 7. & $\begin{array}{l}\text { Sarung } \\
\text { Tangan }\end{array}$ & Sebagai pelindung tangan \\
\hline 8. & Masker & Sebagai pelindung mulut \\
\hline 9. & Oven & Untuk sterilisasi kering \\
\hline 10. & $\begin{array}{l}\text { Kertas } \\
\text { Aluminium } \\
\text { foil }\end{array}$ & $\begin{array}{l}\text { Untuk membungkus cawan } \\
\text { petri }\end{array}$ \\
\hline 11. & $\begin{array}{l}\text { Digital } \\
\text { analitik }\end{array}$ & Untuk menimbang bahan \\
\hline 12. & Cawan petri & $\begin{array}{l}\text { Wadah untuk penumbuhan } \\
\text { bakteri }\end{array}$ \\
\hline 13. & $\begin{array}{l}\text { Jangka } \\
\text { sorong } \\
\text { digital }\end{array}$ & Untuk mengukur bakteri \\
\hline
\end{tabular}

Bahan yang digunakan dalam penelitian ini ditunjukkan pada tabel berikut: 
Tabel 2. Bahan yang digunakan dalam penelitian

\begin{tabular}{cll}
\hline No & \multicolumn{1}{c}{ Bahan } & \multicolumn{1}{c}{ Fungsi } \\
\hline 1. & Aquadest & Untuk melarutkan bahan media uji \\
2. & TSA & Sebagai media uji bakteri \\
3. & Alkohol & Untuk mensterilkan alat \\
4. & Bubuk bawang putih & Bahan utama dalam media uji \\
5. & Ali Meir & Larutan untuk mencampur bahan bubu bawang putih
\end{tabular}

\section{Metode Penelitian}

Metode penelitian ini adalah secara eksperimen menggunakan Rancangan Acak Lengkap dengan empat perlakuan dan satu kontrol. Perlakuan pada penelitian ini terdapat pada konsentrasi larutan bubuk bawang putih yaitu, $0 \% ; 5 \% ; 6 \% ; 7 \%, 8 \%$. Perlakuan yang dilakukan dapat dilihat pada tabel 4 berikut ini.

Tabel 3. Perlakuan Konsentrasi Bawang Putih

\begin{tabular}{cccccc}
\hline No & Perlakuan & Ulangan I & Ulangan II & Ulangan III & Total \\
\hline 1. & $0 \%$ & A1 & A2 & A3 & 3 \\
2. & $5 \%$ & B1 & B2 & B3 & 3 \\
3. & $6 \%$ & C1 & C2 & C3 & 3 \\
4 & $7 \%$ & D1 & D2 & D3 & 3 \\
5 & $8 \%$ & E1 & E2 & E3 & 3 \\
\hline
\end{tabular}

\section{Prosedur Penelitian}

Penelitian ini terdiri dari 4 tahapan, yaitu tahapan sterilisasi alat, pembuatan bubuk bawang putih, pembuatan media pengenceran, dan uji daya hambat.

\section{Sterilisasi Alat}

Semua alat yang digunakan dalam penelitian disterilkan dalam autoklaf pada suhu $121^{\circ} \mathrm{C}$ selama 15 menit dengan cara cawan petri dibungkus dengan aluminium foil, labu ukur ditutup dengan kertas perkamen lalu diikat dengan tali, dan labu erlemeyer diisi dengan akuades sebanyak $250 \mathrm{ml}$ lalu ditutup dengan kapas yang sudah dipadatkan.

\section{Persiapan ekstrak bawang putih}

Proses ekstraksi bawang puith dilakukan dengan merebus bawang putih lalu dihaluskan dengan cara diblender. Setelah dingin baru dilakukan penambahan aquades sucukupnya kemudian disaring dengan menggunakan kertas saring. Setelah itu ekstrak bawang putih dimasukkan ke dalam wadah uji sesuai dosis masing-masing perlakuan untuk dilakukan perendaman selama 30 menit. Kemudian telur uji dimasukkan kedalam wadah penetasan. Selama penelitian, dilakukan perhitungan telur yang menetas dan pengukuran paramater kualitas air.

\section{Parameter Uji}

Pada penelitian ini dilakukan pengamatan Uji daya hambat (zona inhibisi). Persiapan alat dan bahan yaitu: disiapkan lima cawan petri yang telah berisi media, lalu tambahkan lima ose suspensi Edwardsiella tarda pada masing-masing cawan petri. Kemudian pada masing-masing konsentrasi larutan yang telah dibuat, masukkan paper disk. Setelah itu, paper disk tersebut dimasukkan ke dalam masing-masing cawan petri yang digunakan. Sehingga, setiap cawan petri berisi empat paper disk. Inkubasikan ke dalam inkubator selama 1x24 jam.

Daya hambat diketahui berdasarkan pengukuran diameter zona inhibisi (zona bening atau daerah jernih tanpa pertumbuhan mikroorganisme) yang terbentuk di sekitar paper disk. Pengukuran tersebut menggunakan jangka sorong dan dinyatakan dalam milimeter. Data dianalisis 
menggunakan bantuan program SPSS 18.0 digunakan untuk dilakukan Analisis Ragam OVA).

\section{HASIL DAN PEMBAHASAN} Hasil

Uji aktivitas bubuk bawang putih (Allium sativum) terhadap pertumbuhan bakteri dilakukan dengan lima perlakuan: 5\%, bakteri Edwardsiella tarda (Gambar 1.) berbagai konsentrasi bubuk bawang putih $(0 \%, 5 \%, 6 \%, 7 \%, 8 \%)$ telah $\mathrm{di}^{1-1: 2}$ Didapatkan hasil yang bahwa semakin $\mathrm{t} 57$ konsentrasi ekstrak bawang putih maka akan semakin besar hambatan pertumbuhan bakteri Edwardsiella tarda (Tabel 5.). Konsentrasi bawang putih 90\% akan lebih efektif dibandingkan konsentrasi lainnya. Karena hasil dari analisa data tidak menunjukan

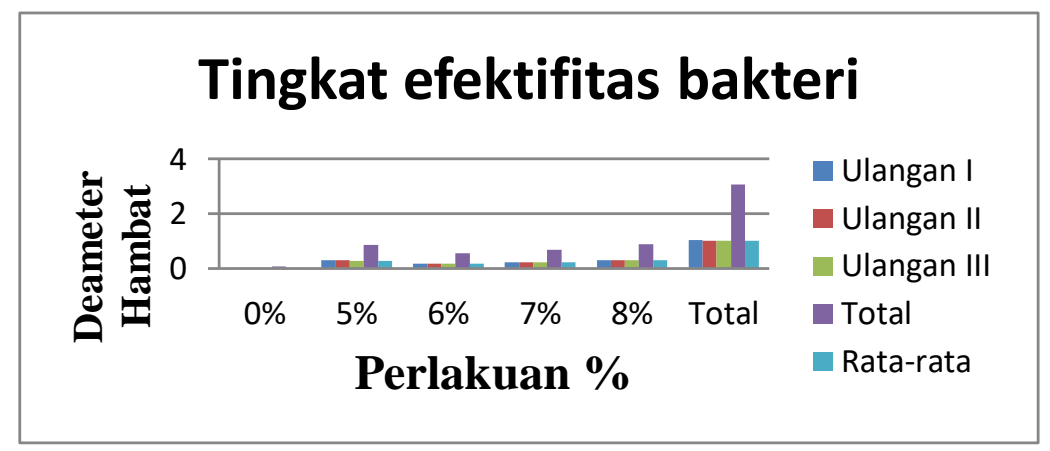

Gambar 1. Tingkat efektifitas bubuk bawang putih (Allium sativum.) terhadap pertumbuhan bakteri Edwardsiella tarda.

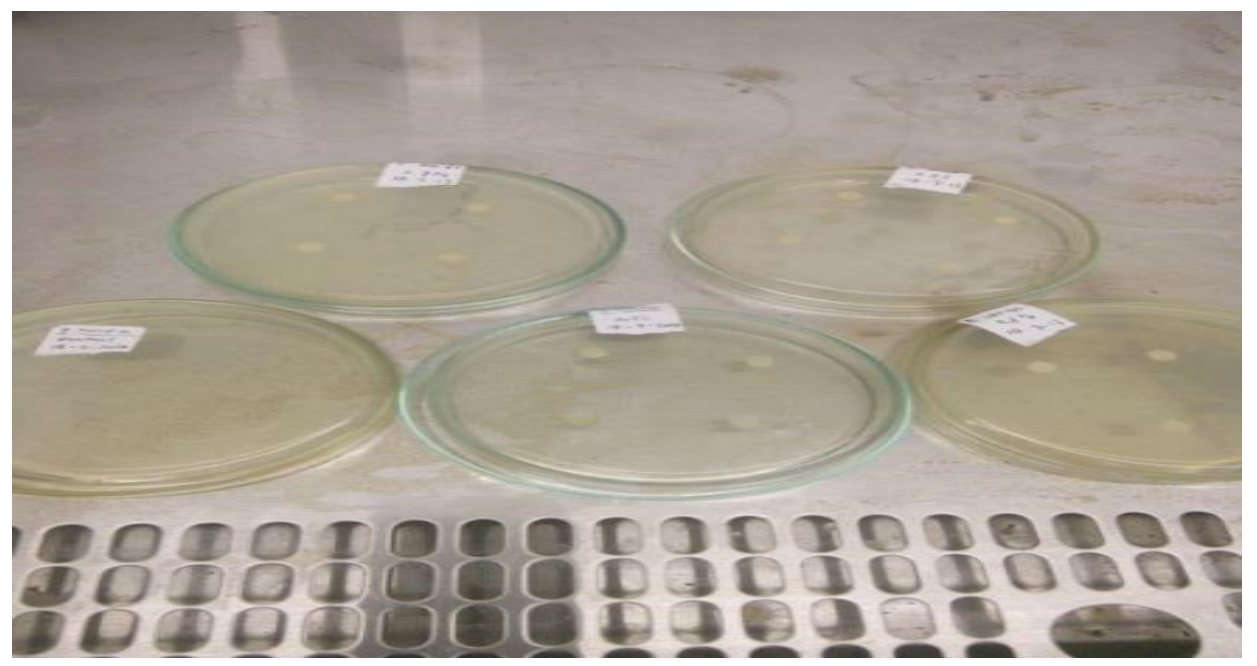

Gambar 2. Hasil Uji Efektivitas Bakteri Edwardsiella tarda

$6 \%, 7 \%, 8 \%$, dan kontrol 0\%. Bakteri

Edwardsiella tarda adalah merupakan bakteri gram-negatif. Bakteri ini didapatkan di karantina ikan Banda Aceh, yang kemudian di lakukan proses pengujian bakteri dilakukan di Laboratorium Kesehatan Ikan Balai Budidaya Air Payau (BBAP) Ujung Batee Kabupaten Aceh Besar Provinsi Aceh. Berdasarkan hasil penelitian uji efetivitas bubuk bawang putih (Allium sativum) terhadap pertumbuhan bakteri Edwardsiella tarda.

Dalam penelitian ini esktrak bubuk bawang putih dapat menhambat pertumbuhan perbedan jauh terhadap hasil penelitian (Gambar 1).

\section{Pembahasan}

Dari hasil penelitian ini terlihat bahwa bubuk bawang putih yang di campur dengan bubuk TSA dan dicampur aquades steril 100 $\mathrm{ml}$ menghasilkan zona hambat pada pertumbuhan bakteri Edwardsiella tarda. Pelarut aquades steril merupakan senyawa polar yang akan dicampur dengan senyawa polar pada tumbukan bawang putih dan senyawa-senyawa lainnya yang memiliki efek antibakteri sehingga terbentuk zona hambat. 
Dapat dilhat dari tabel 5 diatas hasil dari setiap perlakuan dengan 3 kali ulangan tidak menunjukan perbedaan yang terhadap pertumbuhan bakteri, dikarenakan bawang putih (Allium sativum) pengahambat pertumbuhan dari bakteri. Hasil penelitian ini sangat jauh berbeda dengan hasil penelitian Fani et al (2007) yang memperoleh MIC hanya berkisar antara 4 sampai $32 \mu \mathrm{g} / \mathrm{ml}$ (yang diperhitungkan mengandung alicin sebesar $16-128 \mu \mathrm{g} / \mathrm{ml}$ ). Dalam percobaan tersebut, $90 \%$ sampel Streptococcus mutans menunjukkan MIC sebesar $16 \mu \mathrm{g} / \mathrm{ml}$.

Disebut dalam Culter and Wilson (2004) bahwa Alicin yang mewakili 70\%-80\% kandungan thiosulfinat bawang putih akan rusak dalam waktu 16 jam pada suhu $23^{\mathrm{c}}$. sedangkan pemanasan saat evaporasi ekstra sebesar $70^{c}$. Lawson dalam Singh and Singh (2008) menyebutkan waktu Paruh Alicin dalam pelarut etanol adalah 24 jam. Sehingga ada kemungkinan telah rusaknya sebagian zat antibakteri dalam ekstrak

Pada penelitan lain yang dilakukan oleh Puspita, (2008) yang menggunakan variasi konsentrasi $10 \%, 20 \%, 30 \%, 40 \%$, dan $50 \%$ dari bawang putih jenis Allium sativum terhadap bakteri Staphylococcus epidermidis didapatkan hasil pada konsentrasi 20\% merupakan konsentrasi terendah di temukan zona hambat dengan $6 \mathrm{~mm}$.

\section{KESIMPULAN}

Tingkat efektifitas bubuk bawang putih (Allium sativum) terhadap pertumbuhan bakteri Edwardsiella tarda menunjukkan bahwa bawang putih memiliki efek menghambat pertumbuhan bakteri, yang ditunjukkan dari adanya perbedaan antara kontrol dengan perlakuan yang diberikan pada konsentrasi 8\%). Hasil dari analisis data didapatkan bahwa pengaruh daya hambat setiap perlakuan pemberian bubuk bawang putih antara $5 \%, 6 \%, 7 \%, 8 \%$, dan $0 \%$ kontrol berpengaruh terhadap pertumbuhan Edwardsiella tarda dengan nilai F-hitung yang didapatkan lebih kecil dari pada F$0,05 \%$ dan $\mathrm{F}-0,01 \%$.

\section{DAFTAR PUSTAKA}

AAK, 1998. Pedoman Bertanam Bawang. Kanisius, Yogyakarta.

Banerjee, S.K. And S.K. Maulik. (2002). Effect of garlic on cardiovascular disorders: A review. Nutrition J. 1(4):1 $-14$.

Borhan-mojabi K, Shari_M, Karagah T, Karimi H. Efficacy of Diff $\cdots \cdots$ Concentrations of Garlic Extrac

Reduction of Oral Salivary Microoganisms. Arch Iran Med. (2012); 15 (2): 99 - 101.

Culter, R.R. and Wilson, P. 2004. Antibacterial activity of a new, stable, aqueous extract of alicin against methilicillin-resistant Staphylococcus aureus. British Jounal of Biomedical science.

Carson JF. Chemistry and biological properties of onions and garlic. Food Reviews International 1987; (3):71103.

Evennett K. Khasiat Bawang Putih. Wijaya L. Terjemahan. Jakarta: Penerbit Arcan, 2006:2-5.

Ewing, H. W. and P. R. Edward. 1973. Identification of Enterobactericeae By Biochemichal Reaction. Burg ess Publishing Co. Mineapolis. 61-89 P.

Fani, MM, Kohanteb, M.J. and Dayaghi. 2007. Ihibitory activity of garlic (Allium sativum) extract on multidrugresistant Streptococcus mutans. $J$ Indian Soc Pedod Prevent Dent. 164168.

Hindi, Nada Khazal Khadhim. In vitro Antibacterial Activity of Aquatic Garlic Extract, Apple Vinegar and Apple Vinegar - Garlic Extract combination. American Journal of Phytomedicine and Clinical Therapeuticus, Vol. 1, No. 1, 2013, hal. 042-051.

Haryati SA. 2014. Daya hambat ekstrak bawang putih (Allium sativum) terhadap pertumbuhan Streptococcus mutans Secara in vitro. Skripsi. Universitas Hasanuddin.

Iyam Siti S, Tajudin. Khasiat \& Manfaat Bawang putih Raja Antibiotik Alami. Jakarta: Agromedia Pustaka, 2003; 2 $6,12,14$

Kirana, Annisa Nurul. Uji Aktivitas Antimikroba Tumbuhan Kasar Bawang Putih terhadap Staphylococcus aureus secara In-Vitro dengan Metode Difusi. Skripsi: Program Studi Pendidikan Fakultas Kedokteran dan Ilmu 
Kesehatan Universitas Islam Negeri Syarif Hidayatullah Jakarta, 2010.

Lawson, L.D., Wang, Z.J. 2005. Aliciin and alicin-derived garlic compounds increase breath acetone through allyl methyl sulfide: use in measuring alicin biovailability. J Agric Food Chem. 53 (6: 1974-83.

Milner, J.A. 2001. A Historical Perspective on Garlic and Cancer. J. Nutrition. 131: $1027 \mathrm{~S}-1031 \mathrm{~S}$.

Masniari. et al (2004), Poeloengan. Uji Daya Hambat Perasan Umbi Bawang Putih (Alium Sativum) terhadap Bakteri yang Diisolasi dari Telur Ayam Kampung.

Nadirah, M., Najiah M., and Teng S.Y. 2012. Characterization of Edwardsiella tarda Isolated From Asian Seabass, Lates calcalifer. International Food Research Journal 19(3): 1247-1252.

Park, Seong Bin, Takashi Aoki, and Tae Sung Jung. 2012. Pathogenesis of and Strategies for Preventing Edwardsiella tarda Infections In Fish. Veterinary Research, 43:67.

Puspitasari I. Uji Aktivitas Antibakteri Perasan Bawang Putih (Allium sativum) Terhadap Pertumbuhan Bakteri Staphylococcus epidermis in vitro. 2008.

Purwaningsih, Uni dan Taukhid. 2010. Vaksin Anti Streptococcus spp. Inaktivasi Melalui Heatkilled Untuk Pencegahan Penyakit Streptococcosis Pada Ikan Nila (Oreochromis niloticus). Prosiding Forum Inovasi Teknologi Akuakultur. Hal: 901-904.

Syamsiah, I.S dan Tajudin, 2003. Khasiat \& Manfaat Bawang Putih. AgroMedia Pustaka, Jakarta.

Singh, V.K. and Singh, D.K. 2008. Pharmacological effects of garlic (Allium satifum L.) Annu Rev Biomed Sci. 10: 6-26.

Tan, Y.P., Q. Lin, X.H. Wang, S. Joshi, C.L. Hew, and K.Y. Leung. 2002. Comparative Proteomic Analysis of Extracellular Proteins of Edwardsiella tarda. Infections and Immunity Vol. 70 (11): 6475-6480.

Wyatt, L.E., Ranzell Nickelson II, and Carl Vanderzant. 1979. Edwardsiella tarda In Freshwater Catfish and Their Environment. Applied and
Environmental Microbiology Vol. 38 (4): 710-714.

Yamada, Y dan Azma, K. 1997. Antimicroba Agents Chemotheraphy. Diakses dari http://www.Sirisimpex.com/garlic.l 59 diakses pada tanggal 22/03/2016. 